\title{
Effective Method of Natural Gas Pricing in the North Conditions
}

\section{Izabella Damdinovna Elyakova}

\author{
Financial and Economic Institute North-Eastern Federal University named after M.K. Ammosov, Russian Federation, \\ Republic of Sakha (Yakutia), 677000, Yakutsk, 58 Belinsky Street \\ elyak@list.ru
}

\section{Nikolai Nikolaevich Tikhonov}

Financial and Economic Institute North-Eastern Federal University named after M.K. Ammosov, Russian Federation, Republic of Sakha (Yakutia), 677000, Yakutsk, 58 Belinsky Street tikhonovnn36@mail.ru

\begin{abstract}
Aleksandr Alekseevich Pakhomov
Federal State Budgetary Scientific Institution "Yakutsk Scientific Center", Siberian Branch of the Russian Academy of Sciences, Russian Federation, Republic of Sakha (Yakutia), 677000, Yakutsk, 2 Petrovsky Street a.a.pakhomov@prez.ysn.ru
\end{abstract}

\section{Vasilii Romanovich Darbasov}

Federal State Budgetary Scientific Institution "Yakutsk Scientific Center", Siberian Branch of the Russian Academy of Sciences, Russian Federation, Republic of Sakha (Yakutia), 677000, Yakutsk, 2 Petrovsky Street vrdarbasov@mail.ru

\section{Doi:10.5901/mjss.2015.v6n4s4p103}

\section{Abstract}

Main challenges of the regional gas industry functioning in the extreme conditions of the North include a high degree of the main assets wear. It is primarily connected with the lack of geological survey works, absence of the integral gas transport system and lack of investments. The currently existing system of state regulation of the gas producing company's activity in the Sakha (Yakutia) Republic does not allow to maintain the balance of interests between gas enterprises and consumers, and produces a negative impact on the creation establishment stable conditions for the economy functioning and innovative development in the region. The problem of price control in the natural gas market remains particularly acute. A provision for settlement of these challenges is the increase in effectiveness of the state control for the natural gas pricing by means of development of an economically justified pricing method and its application in the state control of the gas wholesale price offered by gas producing companies in the energy-isolated territories of Russia, the mechanism of which is suggested in this article.

Keywords: the North, Republic of Sakha (Yakutia), state control, energetic isolation, economy, company, gas, pricing, wholesale price, methods, costs, profit.

\section{Introduction}

It seems that in the market economy conditions, the state's involvement in the relationships of gas producers and consumers should be minimal. However, it is not the case at all. The vision that economy should be deemed ideal when it is regulated by the Adam Smith's "invisible hand" was proven neither by practical nor by scientific experience. The point is that economy adjustment by the state serves as an organic prerequisite of the possibility of stable economic, including market, relations (Lipsits, 2005).

Government regulation of the economy in the market economy conditions is a system of standard measures of legislative, executive, and controlling nature, carried out by authorized state institutions and public organizations for the purpose of stabilization and adjustment of the existing economy.

In foreign countries with developed and mixed economy, the area of regulated and state-controlled pricing ranges 
from 10 to $40 \%$ of the total output. For example, the share of prices controlled and regulated by the state in Austria achieves $10 \%$, in Italy and China - up to $30 \%$, in the USA — up to 10\%, in France-20\%, in Sweden and Germany-up to $40 \%$, in Japan-up to 20\% (Esipova, 2004).

Gas industry in the Russian Federation forms the basis of the country's foreign economic potential, providing half of the power resources production and consumption. According to Article 4 of the Federal law "Concerning natural monopolies," gas transportation through pipelines is a naturally monopolistic type of activity, and its control and adjustment is carried out by corresponding federal executive bodies (Kolomiichenko, 1995).

Functions of the state control of pricing in the gas supply system are performed by the Federal Tariff Service of Russia (FTS of Russia), which is an authorized federal executive body performing the function of statutory and regulatory acts adoption for the establishment of gas wholesale prices, amounts of remuneration for the supply and distribution services, as well as the tariffs for gas transportation through mainline gas distributing networks (Decree of the Government of the Russian Federation dated March 7, 1995 \#239 "Concerning measures for settlement of the prices (tariffs) state control" (as amended in 2014, \#26 (Part 2), Article 3566); Provisions of the Federal Tariff Service approved by Decree of the Government of the Russian Federation dated June 30, 2004 \#332 (as amended in 2011, \#14)) (Gerasimenko, 2005).

According to this Decree, in the Republic of Sakha (Yakutia), the Federal Tariff Service of Russia sets a wholesale price for natural gas extracted by the JSC Yakutsk Fuel and Energy Company ("YATEC") and the JSC ALROSA-Gaz. Along with that, the Government of the Republic of Sakha (Yakutia) makes suggestions to the FTS of Russia regarding the level of wholesale gas price of enterprises under federal control (Kushlin, 2002). The control over retail prices for gas distributed to the population, the tariffs for the services of gas transportation through the gas distributing networks, the fee for the supply and distribution services rendered by the gas suppliers to end consumers, is performed in compliance with the methodological guidelines approved by the federal executive body in the area of prices (tariffs) state control under agreement with the Ministry of Economic Development and Trade of the Russian Federation.

The federal executive body in the area of prices (tariffs) state control is entitled to delegate in accordance with the established procedure to regional energy commissions the powers for the control of the service tariffs for the services of gas transportation through gas distribution networks and the fee for the supply and distribution services rendered by gas suppliers to end consumers (Decree of the Government of the Russian Federation dated March 7, 1995 \#239 "Concerning measures for settlement of the prices (tariffs) state control" (as amended in 2014, \#26 (Part 2), Article 3566); Provisions of the Federal Tariff Service approved by Decree of the Government of the Russian Federation dated June 30, 2004 \#332 (as amended in 2011, \#14)) (Varlamova, 2010).

On the territory of the Republic of Sakha (Yakutia), the functions of the state control over the gas retail price and adherence to the pricing procedure are imposed on the State Committee for Price Policy - the Regional Energy Commission of the Republic of Sakha (Yakutia).

\section{Literature Review}

The studies demonstrated that the statutory basis of pricing adjustment in the gas supply system almost in all countries (USA, France, Japan, Spain, etc.) is represented by a number of laws determining general order of tariffs adjustment and the procedure of tariffs review, adoption, and application.

As E.V. Malinnikova states in her article, the largest degree of the state interference into the pricing process is observed in France, where the government heavily regulates the prices for gas, electric power, and transport services (Malinnikova, 2005)

Japan has a special governmental body -the Price Bureau of the Economic Planning Agency, which approves gas, prices and carries out control over compliance with the anti-monopoly laws, takes measures for demand maintenance on a proper level, and examines tendencies of demand and supply (Gerasimenko, 2005).

In Greece, the Price Committee establishes tariffs for the electric power, gas, and other prices within the state government competence (Malinnikova, 2005). The legal basis of the state interference into pricing is the Market Regulation Code (Deeva, 2011).

A research of the global and Russian experience in prices and tariffs regulation by countries is presented in the works by larkin, Esipov, Kuzovkin, Kutovoi, Kozlov, Malinnikova, Zhilin (larkin, 2000-2002; Esipov, 2004; Kuzovkin, 2009; Kutovoi, 2001; Kozlov, 2002; Malinnikova, 2005, Zhilin, 2003).

E.V. Iarkin in his article notes that the lawfulness of the state bodies' interference into the activity of gas supply and gas transporting companies must be assessed not only by the enormous impact of the gas industry on the economy and the state budget, as a life-sustaining industry, but also by their impact on the population's welfare. 
Challenges of the state-controlled pricing for the gas of gas extracting and transporting companies, as well as underpricing and its results, are discussed in the works by O.F. Zhilin, E.V. Iarkin. We cannot disagree with the statement that in the modern world gas underpricing not only distort the prices for the electric power and heating, and, further, transport tariffs, but also, as a consequence, the cost of products of all industries. It results in the disrupted objectiveness of sectoral prices, proportions, and all basic macroeconomic indicators of the country. .

Most countries apply certain pricing rules as a general tactics (Volkonskii, 1999). They are adopted as legal acts regulating the procedure and methodology of pricing.

The methodological aspect of pricing in developed countries consists in the generation of common principles, methods, and standards of pricing by state bodies. Beside decision-making with regard to strategic and tactical issues, state bodies undertake the function of introduction of certain prices for goods and services having a decisive significance for the national economy. Along with the direct prices establishment and control, state bodies carry out control over them, as well (Kolomiichenko, 1995).

\section{Materials and Methods}

At present, natural gas extraction in the Republic of Sakha (Yakutia) is quite low and amounts to 1.63 billion $\mathrm{m}^{3}$. In the total natural gas extraction in Russia, its share is equal to $0.28 \%$ (in $2010,583.6$ billion $\mathrm{m}^{3}$ of gas were extracted in Russia, and it is expected that in 2011, the extraction will increase up to 670.5 million $\mathrm{m}^{3}$ ). Gas extraction and gas transporting system of the republic is characterized by its energetic isolation from the unified gas supply system of Russia. Gas supply in the republic is of local nature: its territory is subdivided into the Central, Western, and Srednetiungsky Districts, which are independent and remote from each other.

JSC Yakutsk Fuel and Energy Company extracts natural gas on the Srednevilyuysky gas-condensate field and sells it at the input to the main gas pipeline system of the transporting company JSC Sakhatransneftegaz, which delivers gas to end consumers. The main objective of gas extracting and gas transporting companies is to ensure stable gas supply to consumers of the republic.

The analysis shows that in the future, the role of hydrocarbons in the development of the republic's fuel and energy sector, as well as economy, will keep growing (Lysenko, 2015). The Republic of Sakha (Yakutia) with the richest hydrocarbons reserves is one of the most important regions for the intensive development of the national and Far East region's economy in the future.

The state pricing policy of the Russian Federation in the gas supply area is based on the following principles:

- reimbursement of reasonable expenses associated with the extraction, transportation, processing, storage, distribution, and supply (sale) of gas (under the wholesale prices control condition) to organizations carrying out regulated types of activity, as well as reimbursement of reasonable expenses associated with gas transportation and distribution (under the tariffs control condition);

- setting a reasonable rate of return on capital used in the regulated activities for organizations engaged in such activities (prior to the development of a methodology for determining the amount of fixed assets, other tangible and financial assets used in the regulated activities, the profit margin required to provide these organizations with the means for debt capital servicing, production development, and financing other reasonable expenses, is taken into account);

- meeting the effective demand for gas, achieving a balance between the economic interests of the gas buyers and suppliers;

- accounting of all taxes and other mandatory payments within the regulated prices (tariffs) structure in accordance with the legislation of the Russian Federation;

- accounting of the difference between the cost of transportation services and gas supply (sale) to various customer groups in different areas;

- development of the sectoral (in the gas supply sector) and inter-industry (between substituting types of fuel) competition, as well as application of the method of comparison of the level of gas wholesale prices with the level of gas prices on the foreign markets;

- regulation of gas wholesale prices for gas supply systems, within which gas is supplied to foreign markets, is based on the gas price formula;

- $\quad$ indexing method can be used for setting regulated gas prices (tariffs).

State control on the Russian Federation territory is applicable for:

a) wholesale gas prices; 
b) tariffs for gas transportation through main gas lines for independent organizations;

c) tariffs for the services of gas transportation through pipelines owned by independent gas transporting organizations;

d) tariffs for the services of gas transportation through gas distribution networks;

e) fee for supply and distribution services provided by gas suppliers to end consumers (under gas wholesale prices control condition);

f) retail prices for gas sold to the population;

g) special extra charges to fees for the services of gas transportation through gas distribution networks intended for the gasification programs financing

State control of gas wholesale prices is provided based on the Decree of the Government of the Russian Federation dated March 7, 1995 \#239 "Concerning measures for settlement of the prices (tariffs) state control" and the Provisions of the Federal Tariff Service approved by Decree of the Government of the Russian Federation dated June 30, 2004 \#332 (as amended in 2011, \#14). (Varlamova, 2010).

Over the last twenty years, the pricing policy in the gas sector coordinated with the Federal Tariff Service of Russia has been implemented in the Republic of Sakha (Yakutia). In accordance with this policy, wholesale gas price for gas extracting companies is approved at the federal level of the executive power.

Gas extraction price controlled by the state in the Republic of Sakha (Yakutia) was set by the following methods of state control:

- $\quad$ the price indexation method;

- the method of reasonable costs.

In accordance with price indexation method, indexation of wholesale prices for the natural gas is approved at the forecast level of price deflator indexes of the Ministry of Economic Development of Russia, which does not allow to provide the gas extracting companies JSC Yakutsk Fuel and Energy Company and JSC ALROSA with sufficient investment sources. Moreover, these companies lack means for operating costs due to the high rise of prices for of the suppliers of materials and services.

The method of reasonable costs suggests the establishment of norms and cost standards, as well as application of cost and index methods of expenditure items calculation in case there are no norms and regulations due to objective reasons (Barilenko, 2009).

Table 1 shows the results of a factor analysis of state control of the wholesale gas prices of JSC Yakutsk Fuel and Energy Company in 2013.

Table 1. Factor analysis of cost items impact on the gas extraction wholesale price of JSC Yakutsk Fuel and Energy Company in 2013 (in thousand rubles).

\begin{tabular}{|c|c|c|c|c|c|c|}
\hline № & Parameters & Approved price & Actual price & $\begin{array}{c}\text { Absolute } \\
\text { deviation }(+,-)\end{array}$ & $\begin{array}{c}\text { Relative } \\
\text { deviation, } \%\end{array}$ & Factors impacting gas extraction price \\
\hline 1. & Revenue & $2,454,631.00$ & $2447,960.00$ & $-6,671.00$ & 99.7 & $\begin{array}{l}\text { Decrease in the approved revenue by } \\
6.7 \text { million rub. }\end{array}$ \\
\hline 2. & Cost, including: & $1,690,222.00$ & $1,716,523.00$ & $26,301.00$ & 101.6 & \\
\hline 2.1. & Material expenses & $124,547.00$ & $84,628.00$ & $-39,919.00$ & 67.9 & \\
\hline 2.2. & Wages fund with deductions & $346,551.00$ & $389,997.00$ & $43,446.00$ & 112.0 & $\begin{array}{l}\text { 1) Decrease in the actual workforce and } \\
\text { increase in the number of managers } \\
\text { 2) Increase in the minimal wage rate of } \\
\text { a } 1^{\text {st-category worker and increase in }} \\
\text { the contract salaries }\end{array}$ \\
\hline 2.3. & Depreciation & $321,778.00$ & $371,461.00$ & $49,683.00$ & 115.4 & Fixed assets revaluation \\
\hline 2.4 . & Burden expenses & $272,164.00$ & $326,919.00$ & $54,755.00$ & 120.1 & $\begin{array}{l}\text { Increase in the administrative expenses } \\
\text { in proportion to the cost of gas } \\
\text { extraction }\end{array}$ \\
\hline 2.5. & Taxes within the cost & $423,455.00$ & $449,817.00$ & $26,362.00$ & 106.2 & Increase in gas extraction volumes \\
\hline 2.5 .1 & Mineral extraction tax & $416,582.00$ & $443,549.00$ & $26,967.00$ & 106.5 & Increase in gas extraction volumes \\
\hline 3. & Sales profit & $764,409.00$ & $731,437.00$ & $-32,972.00$ & 95.7 & \\
\hline 3.1 & Operating expenses & $128,732.00$ & $158,826.00$ & $30,094.00$ & 123.4 & \\
\hline 3.1.2. & Property tax & $68,732.00$ & $68,294.00$ & -438.00 & 99.4 & Fixed assets revaluation \\
\hline 3.1.3. & Credit interest (for the cash gap) & $60,000.00$ & $90,532.00$ & $30,532.00$ & 150.9 & Excess due to attraction of new credits \\
\hline 3.2. & Non-operating expenses & $509,855.00$ & $398,740.00$ & $-111,115.00$ & 78.2 & \\
\hline 3.2.1. & Consumption fund & $19,917.00$ & $52,435.00$ & $32,518.00$ & 263.3 & $\begin{array}{l}\text { Excess plan due to the payment of lump } \\
\text { sum compensation in accordance with } \\
\text { the employment agreement }\end{array}$ \\
\hline
\end{tabular}




\begin{tabular}{|c|l|c|c|c|c|l|}
\hline 3.2.2. & Capital investments & $380,000.00$ & $331,333.00$ & $-48,667.00$ & 87.2 & $\begin{array}{l}\text { Non-implementation of the company's } \\
\text { investment program }\end{array}$ \\
\hline 3.3 & Profit tax & $125,822.00$ & $173,871.00$ & $48,049.00$ & 138.2 & $\begin{array}{l}\text { Introduction of revenue distribution } \\
\text { principle }\end{array}$ \\
\hline 4. & Profitability, \% & $45.2 \%$ & $42.6 \%$ & -2.6 & 94.2 & \\
\hline 5. & $\begin{array}{l}\text { Gas wholesale price rub./thousand } \\
\text { cubic meters }\end{array}$ & $1,499.00$ & $1,470.5$ & -29.00 & 98.1 & \\
\hline
\end{tabular}

Results of the factor analysis of the cost items impact on the gas extraction wholesale price of JSC Yakutsk Fuel and Energy Company in 2013 allow to draw a conclusion, that in 2013, the actual wholesale price of the extracted gas was lower than the price set by the Federal Tariff Service of Russia by $2 \%$.

The main factor of the wholesale gas price reduction in the JSC Yakutsk Fuel and Energy Company in 2013 is an increase in extraction volumes due to the objective growth of demand for gas by power plants and boiler-houses of the Republic of Sakha (Yakutia) caused by the low ambient temperatures, which was not planned in the approved gas wholesale price.

An analysis of the results of gas wholesale pricing of the JSC Yakutsk Fuel and Energy Company in 2013 showed that the actual gas wholesale price was 1,470.5 RUR. /1,000 $\mathrm{m}^{3}$ instead of the approved wholesale gas price of 1,499 $\mathrm{RUR} / 1,000 \mathrm{~m}^{3}$

Thus, the following changes in the price-forming factors were not accounted in the approved price in 2013:

1) The amount of marketable gas taken into account for the calculation of the wholesale price for 2013 amounted to 1.6647 billion $\mathrm{m}^{3}$, which is by $2 \%$ higher than the targets within the approved gas wholesale price. This is due to a lower temperature during the heating period.

2) Significant deviations that affected the growth in the gas extraction prime cost occurred due to the overspending in the following expense items:

- "Wages fund with deductions" due to reduction in the actual number of workers and increase in the managerial staff number; the increase in the minimal wage rate of a $1^{\text {st }}$ category worker, and the increase in contract salaries;

- "Depreciation" due to the revaluation of fixed assets;

- "Burden expenses" due to the increase in administrative expenses in proportion to the gas extraction prime cost;

- "Taxes within the cost" due to the increase of the gas extraction volumes;

- "Credit interest" due to the excess caused by attraction of new loans;

- "Consumption fund" due to the payment of lump-sum compensations in accordance with the employment agreement;

- $\quad$ "Profit tax" due to the proportional distribution of the revenue for gas extraction.

3) Factors constituting the wholesale gas price, which affected the decrease in the net cost, are as follows:

- "General overhaul" due to managerial decisions on reducing the plan of overhauls;

- "Third party services" due to the reduction in expenses on the fire, militarized, and watchman security service, as well as on the inland water transport maintenance;

- "Expenses for social objects" due to costs optimization;

- $\quad$ "Capital investments" due to non-fulfillment of the investment program in full.

Upon an analysis of the factors affecting the price of the natural gas extraction, it was discovered that wages fund (18\%), depreciation (21.6\%), burden expenses (19\%), and taxes within the cost (26.2\%) take the largest share in the gas extraction cost within the approved price. In 2013, the gas extraction cost of the JSC Yakutsk Fuel and Energy Company amounted to 2,447.96 million rubles, which was higher than the target expenses by $1.5 \%$, while the revenue was lower by $0.3 \%$. During the analyzed year, the company made a profit from the regulated activities in the amount of 731.4 million rubles with the sales profitability of $42.6 \%$.

However, in spite of the visible well-being, there are serious problems in the republic's gas industry, which include a high level of the fixed assets deterioration, insufficient exploration work, especially the absence of an integral gas transportation system and lack of investments (Borisov, 2014).

Also, the existing system of state regulation of the gas extracting company in the Republic of Sakha (Yakutia) does not allow to provide the balance of interests of the gas enterprises and consumers, and has a negative impact on the establishment of stable conditions for the economy functioning and innovative development in the northern region.

The most acute problem is price control in the natural gas market; an effective mechanism of the gas prices state 
control is missing, which leads to the necessity of its improvement, as well as development of the effective methods of pricing at gas extracting companies with the account of peculiarities of their operation and gas supply on the energetically isolated territories of Russia.

These problems may be solved by increasing the efficiency of state control over natural gas pricing, for example, by the development of an economically justified pricing method and its application under the conditions of state adjustment of the gas wholesale price offered by the gas extracting companies on the energetically isolated territories of Russia, the mechanism of which will be suggested further.

The results of the performed factor analysis of state control over the wholesale gas price of the JSC Yakutsk Fuel and Energy Company in 2013 allow us to draw up the conclusion that the federal and regional regulatory executive bodies have to use the method of reasonable costs based on the factor analysis of the costs impact on the wholesale price of gas extraction for the past year, and set the wholesale gas price for the target period with account of their impact.

In such an energetically isolated region as the Republic of Sakha (Yakutia), it is economically justified to apply the method of reasonable costs for calculating the wholesale price for gas extraction within the system of state control of the wholesale gas prices. An economically justified method for calculating the wholesale price of gas extraction will be based on the factor analysis of gas sale costs of the gas extracting companies, which will allow to compare target and actual expenses for the reference period of the gas wholesale price control and identify the validity of all the expenses. It is suggested to take into account the results of the factor analysis of changes in the natural gas extraction cost for the reference period of the company's activity in the next planned regulated period of gas pricing.

\section{Results and their Discussion}

In our opinion, in order to develop an effective method of pricing for the natural gas extracted by the JSC Yakutsk Fuel and Energy Company, it would be expedient to group the main factors affecting the price level.

External factors that usually do not depend on the company or not controlled by it:

- emergencies, natural and climatic conditions, transport and other factors, which cause additional costs for some companies and additional profit for other companies;

- changes by state bodies or by inflationary processes in the price for products, consumed raw materials, fuel and methanol; tariffs for services and transportation; trade discounts; extra charges; depreciation standards; wage rates, extra charges on it, taxes, and other fees paid by enterprises;

- violation of discipline related to economic issues affecting the company's interests by suppliers, customers, supply/sale organizations, supervising economic, financial, banking, and other bodies.

Internal factors depending on the company and controlled by it:

a) Main factors of gas extraction pricing:

- quantity and quality of the natural gas extracted by the JSC Yakutsk Fuel and Energy Company;

- product prime cost;

- product prices;

- prime cost elements;

- structural changes in the product composition.

In general, the wholesale price for gas production $(P)$ is determined by the following formula:

$P=N /$, (1)

where $N$ is net revenue, $V$ is the volume of marketable gas.

The revenue depends not only on the quantity and quality of the produced gas, but also on the cost structure of gas production (cost items) and the level of prices for gas production. In turn, the cost of gas is determined by the structure of fixed and variable costs (salaries, methanol, and so on) and the prices for several cost elements.

b) Factors determined by the violation of economic discipline:

- violation of the current procedure for setting and applying gas extraction prices;

- savings resulting from non-fulfillment of the measures of labor protection, working conditions improvement, and safety provided in the employment agreement, under-utilization of funds for training and advanced training of personnel, failure to carry out the plan for maintenance of fixed production assets of gas supply facilities, failure to carry out testing and development of new drilling equipment, etc.;

- savings resulting from the sale of gas with deviations from the terms of gas supply contracts, its quality standards, specifications and violations of the gas extraction technology.

The production and revenue level of the JSC Yakutsk Fuel and Energy Company is affected mostly by the objective parameter-the demand of the power industry and housing and communal services of the northern region, in 
most cases determined by the temperature conditions of the heating period in Yakutia. The longer the period of low temperatures, the more gas is consumed by the companies. Therefore, the changes in production volumes can only be taken on actual basis as of the end of the financial year. Accordingly, all reasonable changes in variable costs within the cost of gas extraction should be corrected in the target regulation period in the form of savings or cost overruns.

In order to determine the effect of one factor of gas extraction costs, we assume that other factors remain unchanged, i.e. in this case the cost of methanol is variable $(V C)$, and other expenses are constants $(F C)$ :

$T C=V C+F C$

The absolute gain in the total costs depends on the value of the variable factor and the relative gain in the variable factor:

$\Delta T C=V C \times \triangle V C / V C$

Therefore, the relative gain in the total cost is determined by the following formula:

$\Delta T C=\Delta V C / V C \times V C / T C$

Thus, the dynamics of total costs of the JSC Yakutsk Fuel and Energy Company under the conditions of inelasticity of the demand for gas depends directly on the dynamics of variable costs of natural gas extraction.

A detailed factor analysis of natural gas extraction price can be presented in the context of the elements of costs. In addition, it can be expressed by the integrated factors such as gross revenue, the prime cost of natural gas extraction, selling and administrative expenses of the enterprise.

In order to use this economically justified method of pricing for the purpose of the factor analysis in the gas extracting companies of the northern region, it is necessary to arrange appropriate analytical accounting on the business accounts of the JSC Yakutsk Fuel and Energy Company, which accumulate the information about the above-specified integrated factors. Upon availability of the necessary analytical data, a detailed factor analysis can be carried out more accurately.

The result of such a detailed factor analysis allows to determine elements of costs producing the greatest (or smallest) impact on the extraction price, the factors causing it, and the way, in which such factors affect the change of the gas extraction price. A detailed factor analysis of the costs affecting the price of natural gas extraction allows to determine the effectiveness level of the state control and take managerial decisions on adjustment of the level of the elements of costs in the current period or in the target regulation period.

The suggested economically justified method of state regulation of gas extraction wholesale prices in the North takes into account the specific character of gas supply in the Republic of Sakha (Yakutia), first of all its energetic isolation from the unified gas supply system of Russia, where market mechanisms of gas pricing do not work because of the impossibility to create a competitive environment among gas extracting companies. As it was mentioned above, gas supply in the local areas of the Republic of Sakha (Yakutia) is provided in the central power district by JSC Yakutsk Fuel and Energy Company and in the western power district by JSC ALROSA-Gaz.

\section{Conclusion}

The most economically justified and effective method of state control over the natural gas pricing in the conditions of energetic isolation in the North consists in the application of the costs impact factor analysis and determination of the economically justified prime cost of the natural gas extraction in the republic. The costs factor analysis is currently a more effective method that the applied method of justified costs in the price determination, which is applied by the federal and regional state executive bodies.

Application of the suggested economically justified method for the natural gas pricing would allow to perform effective state control over its extraction with account of the gas industry development prospects in the Republic of Sakha (Yakutia).

The suggested economically justified method of the state control over wholesale gas prices of the gas extracting companies of the Republic of Sakha (Yakutia) can be also applied in other regions of the North isolated from the Russian territories with the unified gas supply system, such as the Kamchatka Region, the Sakhalin region, and others.

\section{Acknowledgments}

The authors express their gratitude for the provided practical materials on the researched topic to the Head of the Planning and Economic Department of the JSC Sakhatransneftegaz Bulgytova Alla Ruslanovna, First Deputy of the State Pricing Policy Committee - the Regional Energy Commission of the Republic of Sakha (Yakutia) Koriagina Natalia lurievna. 


\section{References}

Barilenko, V.I. (2009). Analiz khoziaistvennoi deiatel'nosti [Analysis of economic activity]. Moscow: Omega-L [in Russian].

Bazdnikov, A.S. (2005). Tseny i tsenoobrazovanie [Prices and pricing]. Moscow: lurait [in Russian].

Borisov, K.A., \& Darbasov, V.R. (2014). Agroposelok na Severe [An agrarian settlement in the North]. Yakutsk: Bichik [in Russian].

Deeva, A.I. (2011). Tsenoobrazovanie [Pricing]. Moscow: KNORUS [in Russian].

Gerasimenko, V.V. (2005). Tsenoobrazovanie [Pricing]. Moscow: INFRA [in Russian].

Ginzburg, A.I. (2008). Ekonomicheskii analiz: Uchebnik dlia vuzov [Economic analysis: Textbook for universities] (2nd ed., rev. and add., Series "Textbook for high schools"). St Petersburg: Piter [in Russian].

Esipova, V.E. (2004). Tseny i tsenoobrazovanie [Prices and pricing] (4th ed.). St Petersburg: Peter [in Russian].

Kanke, A.A., \& Koshevaia, I.P. (2008). Analiz finansovo-khoziaistvennoi [Analysis of financial and economic activity of an enterprise]. Moscow: ID «FORUM»: INFRA-M [in Russian].

Kolomiichenko, O.V., Kotelkina, E.I., \& Sokolova, I.P. (1995). Regulirovanie estestvennykh monopolii: Analiz mirovogo opyta i postroenie sistemy regulirovaniia $v$ Rossiiskoi Federatsii [Regulation of natural monopolies: Analysis of international experience and building of the regulation system in the Russian Federation]. St Petersburg [in Russian].

Kushlin, V.I. (2002). Gosudarstvennoe regulirovanie rynochnoi ekonomiki [State regulation of the market economy]. Moscow: RAGS [in Russian].

Lipsits, I.V. (2005). Tsenoobrazovanie [Pricing]. Moscow: Ekonomist [in Russian].

Lysenko, D.V. (2008). Ekonomicheskii analiz [Economic analysis]. Welbi prospekt [in Russian].

Informatsiia 0 itogakh regulirovaniia tsen (tarifov) GKTs-REK RS(la) na $2013 \mathrm{~g}$. [Information on the outcome of the prices (tariffs) regulation of the National Committee for Price Policy of the Regional Energy Commission of the Republic of Sakha (Yakutia) for 2013] [in Russian].

Varlamova, A.N. (2010). Pravovoe obespechenie razvitiia konkurentsii [Legal support of the competition development]. Moscow: Statut [in Russian].

Volkonskii, V.A., Gurvich, E.T., \& Ovsienko, V.V. (1999). Nekotorye tsenovye i finansovye problemy TEK [Some price and financial problems of fuel and energy sector]. Vestnik FEK - Bulletin of the Federal Energy Commission, 126 [in Russian]. 